was a signatory, actually refers to the names of taxa as proper names"), and be excited by the vigour of the prose from which Ghiselin's personality is inseparable. I waffled (in the oscillatory American sense) between the two. Either way, it is now the standard source for anyone who wants to find out what it means to call a species an individual.

Mark Ridley is in the Department of Zoology,

University of Oxford, Oxford OX1 3PS, UK.

\section{Novel adaptation}

\section{Enduring Love}

by Ian McEwan

Cape/Doubleday: 1997. Pp. 247. £15.99, \$23.95

\section{Marek Kohn}

If our minds contain modules adapted to detect cheating, as the evolutionary psychologist Leda Cosmides has proposed, we run the risk that these organs will reach uncomfortable conclusions about the individuals they have most opportunity to observe: ourselves. The people who are best at deluding others are those who are best at deluding themselves, reflects Joe Rose, the narrator of Enduring Love; they flourish, and so do their genes. But his powers of persuasion are not so well developed. His genes have not flourished either, because this is a Darwinian morality tale.

His commercial timing as a writer has been perfect, however. He has surfed every wave in the popular science tide: dinosaurs, black holes, quantum magic, superstrings, neuroscience, Darwin revisited.... But now it is too late for him to follow the career in scientific research that, according to the voice of his conscience, was his true calling. At one point he writes an article arguing that Victorian scientists were the last to enjoy the pleasure of narrative in their papers, and then realizes it does not stand up; it was not written in the pursuit of truth; it was not science but journalism. Ian McEwan also takes his science seriously, and for many years regretted doing English rather than a science degree.

Despite carrying too much guilt, too much bulk and too little hair, Joe enjoys the love of a beautiful young woman. He cannot quite believe his luck, but no neo-Darwinian mate-choice theorist would be surprised. And his partner Clarissa is unable to have children. The couple remain on a plateau of erotic arousal, enjoying endless proximal rewards without an ultimate goal, cheating the evolutionary system as well as the intellectual one.

Then, one day in the countryside outside London, Clarissa and Joe see a balloon in trouble. Joe is one of several men who throw themselves into the scene, assembling a fatally ad hoc male coalition. Any primatologist will tell you that if you were a boy about to be car-

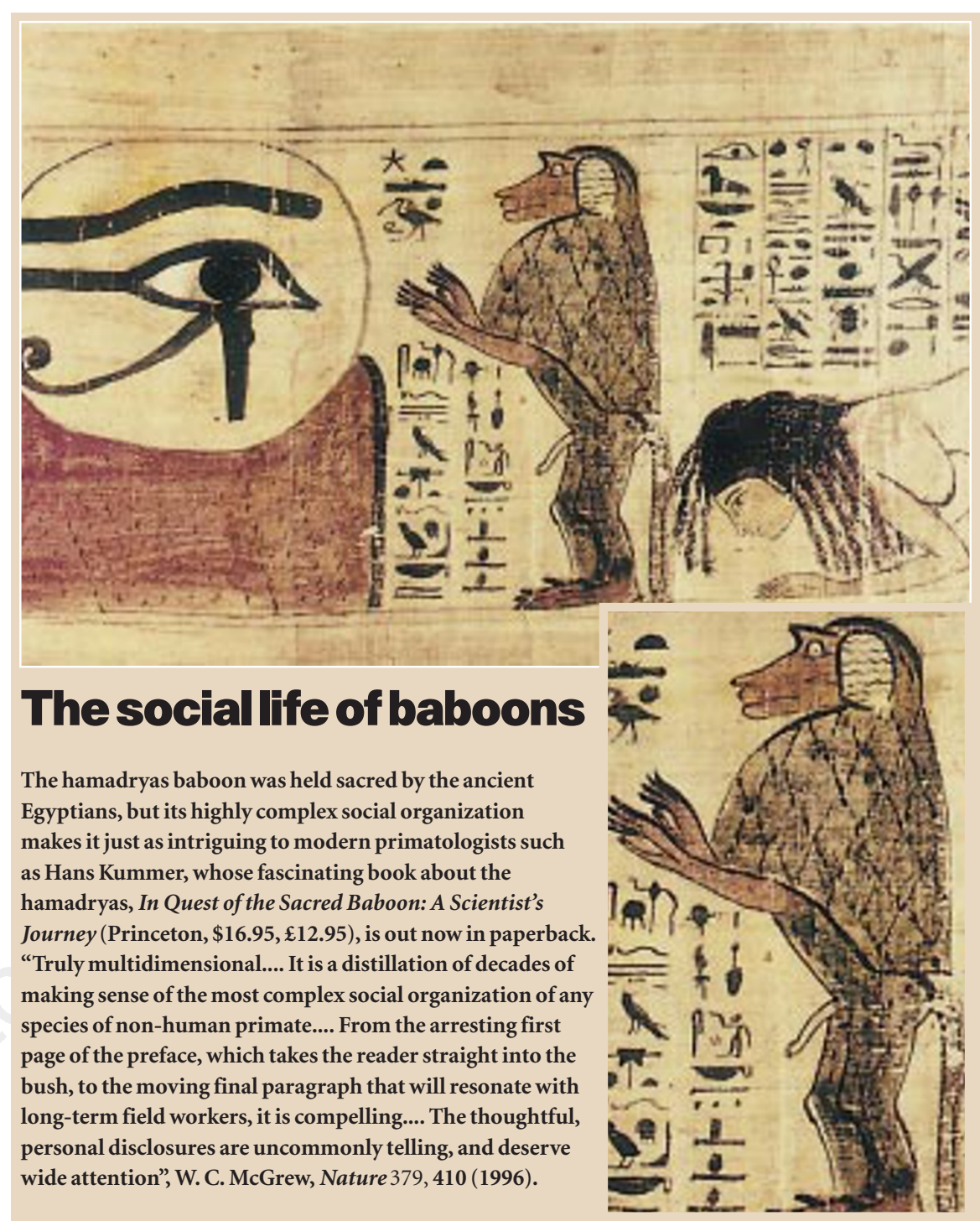

ried away in a balloon, you would be misguided to place your trust in a coalition of unrelated males who did not know each other. As the balloon rises, one man lets go. The balance of interests is upset: the value of cooperation collapses, and that of defection soars. Others then drop off, including Joe, but the last man hangs on. He is killed; the boy survives.

As well as the death, there is a second cataclysmic moment within this drama. One of the rescuers is a young man, Jed Parry, whose unconditional religious faith is suddenly joined by an equally absolute conviction that he and Joe are destined to be together in Christ. Joe diagnoses de Clérambault's syndrome, in which the subject believes the object of the obsession to be in love with him, however strong the evidence to the contrary. Jed's menacing ecstasy batters away at Joe's sanity, and pulls apart the bonds between Joe and Clarissa. On one side is the narrator's voice of reason; on the other are the Jesus freak's deranged faith and the Romantic inclinations of Clarissa, a student of Keats. Science finds both art and religion ranged against it.
As narrator, however, Joe has also been given the benefit of comprehensive emotional literacy, in reflection if not in dialogue. He fails to realize, for instance, that barren Clarissa might not care to hear his speculations about the adaptive value of a baby's smile. Joe is particularly taken with Ekman's recent work in the same field.

These scientific interpolations work better than the obvious oppositions between science and unreason. But the most effective science in Enduring Love is that which is not completely spelled out. The dynamics of the balloon coalition are one instance; another is the inexorable intrusion of reproductive interests, subtly evoked in Joe's encounters with the children of the dead man.

McEwan's final scientific flourish is an appendix, a cod scientific paper that recapitulates the story as a case history of de Clérambault's syndrome. Into this he drops a throwaway happy ending, thereby nailing the lid on Joe's vain thesis about science losing the plot.

Marek Kohn is at Flat 3, 27 Warrington Crescent, London W9 1ED, UK. Darwin's Expression of the Emotions and Paul 